\title{
PENGARUH MARKETING MIX TERHADAP MINAT BELI KONSUMEN PADA USAHA MIKRO KECIL DAN MENENGAH (UMKM) PRODUK OLAHAN MAKANAN RINGAN
}

\section{THE EFFECT OF MARKETING MIX TO CONSUMEN WILLINGNESS TO BUY IN MICRO SMALL MEDIUM ENTERPRISES (MSME) SNACKS PRODUCT}

\author{
E Silaningsih ${ }^{1 a}$ dan P Utami ${ }^{1}$ \\ 1 Universitas Djuanda Bogor, Jawa Barat, Indonesia \\ a Korespondensi: Endang Silaningsih, Email: endang.silaningsih@unida.ac.id \\ (Diterima: 17-06-2018; Ditelaah: 18-06-2018; Disetujui: 18-10-2018)
}

\begin{abstract}
The purpose of the research is to determine the effect of marketing mix to consumen willingness to buy in Micro Small Medium Enterprises (MSME) snacks product in Bogor City. There were 100 people consumen sampled. The methods used in this research are survey method, description and verification. The data collected by interview and gave a quitsionnaire to respondents. The test used are validity test, relliability test and analysis multiple correlation.Based on the validity and reliability test, the result showed all imdicators expressed validity and reliability. Silmutaneously product, price, place and promotion influencing the consumen's wilingness to buy in Micro Small Medium Enterprises (MSME) snacks product in Bogor City. Partially product and price give both positive and significant effect the consumen willingness to buy in Micro Small Medium Enterprises (MSME) snacks product in Bogor City, whereas place and promotion given't both positive and significant effect the consumen wiliingness to buy in Micro Small Medium Enterprises (MSME) snacks product in Bogor City. Variabel product become the most dominant factor affecting consumen's willingness to buy.
\end{abstract}

Key words: marketing mix, consumens willingness to buy, snacks.

\begin{abstract}
ABSTRAK
Tujuan penelitian untuk menentukan pengaruh marketing mix terhadap minat beli konsumen pada Usaha Mikro Kecil dan Menengah (UMKM) produk olahan makanan ringan di Kota Bogor. Jumlah sampel yang diambil sebanyak 100 orang konsumen. Metode yang digunakan adalah metode survey, bentuk penelitian yang digunakan dalam penelitian verifikatif dan deskriptif. Pengumpulan data dilakukan melalui interview dan penyebaran angket pada responden. Kuesioner tersebut di uji menggunakan uji validitas, uji reliabilitas serta uji asumsi klasik. Hasil penelitian menunjukkan produk, harga, tempat dan promosi berpengaruh secara simultan pada minat beli konsumen. Secara parsial harga dan produk berpengaruh pada minat beli konsumen, sedangkan promosi dan tempat tidak memiliki pengaruh pada minat beli konsumen. Variabel produk menjadi yang paling kuat memiliki pengaruh pada minat beli konsumen.
\end{abstract}

Kata kunci: marketing mix, minat beli konsumen, makanan ringan.

Silaningsih, E. \& Utami, P. (2018). Pengaruh Marketing Mix Terhadap Minat Beli Konsumen pada Usaha Mikro Kecil dan Menengah (UMKM) Produk Olahan Makanan Ringan. Jurnal Sosial Humaniora 9(2): 144-158. 


\section{PENDAHULUAN}

Arus globalisasi perdagangan internasional adalah fenomena yang menerjang hampir seluruh negara. Derasnya arus globalisasi aktif dalam pengembangan ekonomi negaranegara berkembang berakibat pada persaingan di sektor industri. Usaha Mikro Kecil dan Menengah ialah satu diantara usaha di Indonesia yang mampu memberikan kontribusi cukup besar dan memiliki potensi berkompetesi di pasar Internasional. UMKM mempunyai peranan penting dan strategis dalam pembangunan ekonomi nasional. UMKM juga terbukti tidak terpengaruh terhadap kirisis. Ketika krisis ekonomi melanda tahun 1997-1998, hanya usaha tersebut yang dapat berdiri kokoh. Data dari Badan Pusat Statistik menunjukkan bahwa setelah masa krisis ekonomi jumlah UMKM tidak mengalami penurunan dan terus meningkat serta mampu menyerap 85 juta hingga 107 juta tenaga kerja sampai tahun 2012. Pada tahun itu jumlah pegusaha di Indonesia sebanyak 56.539.560 unit. Dari jumlah tersebut, sebanyak 56.534.592 unit adalah UMKM atau 99,99\%. Sisanya sekitar 0,01\% merupakan usaha termasuk kategori besar. Hal itu membuktikan bahwa UMKM terus tumbuh dan mampu beridiri sebagai pelaku ekonomi yang tangguh, unggul serta tahan krisis. Pertumbuhan UMKM ini merupakan potensi ekonomi yang wajib mendapatkan perhatian oleh berbagai pihak agar UMKM dapat terus bersaing dipasar lokal maupun global. Arus globalisasi semakin maju, maka keinginan konsumen semakin cepat untuk berganti, tidak hanya itu konsumen juga kian selektif. Oleh sebab itu, pihak UMKM dituntut untuk memahami serta mempelajari bagaimana perilaku konusmen dalam memutuskan pembelian dalam usahanya mencukupi keinginan dan keinginan. Untuk lebih meningkatkan minat beli, maka pihak perusahaan perlu memperhatikan strategi bauran pemasaran. Alma (2005) berpendapat bahwa analisis kemampuan strategi pemasaran suatu produk terletak pada penguasaan, impilkasi serta pemahaman mengenai cara-cara pemasaran yang berpusat pada marketing mix/bauran pemasaran. Dimana bauran pemasaran yang dimaksud yaitu promosi, temoat, harga dan promosi. Definisi marketing mix menurut Assauri (2007) adalah penggabungan antar kegiatan atau variabel yang merupakan poko dari suatu sistem pemasaran, kegiatan mana yang bisa terorganisasi oleh pemasaran agar mampu mempengaruhi respon konsumen. Kemajuan globalisasi saat ini, berakibat pada cepat berubahnya selera konsumen dan juga akan menjadi selektif. Agar perekonomian bisa berkembang dan tumbuh mengikuti selera konsumen maka perusahaan perlu memahami, mempelajari keperluan dan kepentingan konsumen. Minat beli pada konsumen merupakan sikap yang muncul sebagai tanggapan tehadap objek yang menandakan ketertarikan atau keinginan konsumen membeli suatu produk. Bagi konsumen, pasar yang menyediakan berbagai macam subtitusi produk serta merek yang beragam membuat konsumen dapat memilih produk secara bebas. Jika produk bisa mencukupi keinginan dan kebutuhan konsumen, maka konsumen tersebut tentu saja akan membeli produk yang ditawarkan tersebut. Maka dari itu, penting sekali memahami pengaruh marketing mix terhadap minat beli konsumen pada UMKM produk olahan makanan ringan di Kota Bogor yang ditujukan meningkatkan minat beli konsumen.

\section{MATERI DAN METODE}

\section{Minat Beli Konsumen}

Minat beli merupakan tahapan keinginan konsumen dalam berperilaku sebelum keputusan saat membeli produk benarbenar dilakukan. Menurut Ferdinand (2002) minat beli merupakan apapun yang berhubungan dengan perencanaan dalam membeli produk dan jumlah unit yang diperlukan pada waktu tertentu pada konsumen. Sedangkan menurut Kotler 
(2002) minat beli yaitu sikap yang tampak sebagai reaksi pada objek memperlihatkan keinginan konsumen dalam melaksanakan pembelian. Sedangkan pengertian minat beli lainnya adalah sesuatu yang berhubungan dengan langkah konsumen membeli produk tertentu (Durianto dkk, 2003).

\section{Bauran Pemasaran}

Strategi pemasaran merupakan suatu komponen yang secara layak, tepat serta konsisten dilakukan oleh perusahaan untuk memperoleh pasar sasaran yang dituju dalam jangka panjang dan tujuan perusahaan jangka pendek pada keadaan kompetisi tertentu. Bauran pemasaran ialah sekumpulan instrumen pemasaran yang dipakai perusahaan sehingga berkelanjutan menggapai tujuan pemasarannya di pasar sasaran, yang terbagi menjadi 4 (empat) komponen seperti harga, promosi, tempat dan produk (Kotler dan Amstrong, 2012). Sedangkan menurut Swastha dkk (2000) bauran pemasaran adalah kombinasi atau perpaduan dari empat variable pokok dari sistem pemasaraan pada perusahaan yaitu sistem distribusi, kegiatan promosi, produk dan struktur harga,. Dari definisi beberapa ahli bisa disimpulkan jika bauran pemasaran yaitu segala kegiatan yang dikombinasikan sebagai pemuasan kebutuhan konsumen, dimana terdiri dari product, promotion, price, place.

\section{Usaha Mikro Kecil dan Menengah (UMKM)}

Berdasar Undang-Undang No. 20 tahun 2008 tentang Usaha Mikro Kecil Menengah (UMKM), ada beberapa kriteria yang dipergunakan untuk mendefinisikan pengertian dan kriteria Usaha Mikro Kecil dan Menengah. Pengertian-pengertian UMKM tersebut adalah :

\section{Usaha Mikro}

Usaha Mikro adalah usaha produktif milik orang perorangan dan / atau badan usaha perorangan yang memenuhi kriteria Usaha Mikro sebagaimana diatur dalam UndangUndang ini.

2. Usaha Kecil

Kriteria Usaha Kecil Adalah usaha ekonomi produktif yang berdiri sendiri, yang dilakukan oleh orang perorangan atau badan usaha yang bukan merupakan anak perusahaan atau bukan cabang perusahaan yang dimiliki, dikuasai, atau menjadi bagian baik langsung maupun tidak langsung dari usaha menengah atau usaha besar yang memenuhi kriteria usaha kecil sebagaimana dimaksud dalam UndangUndang ini.

\section{Usaha Menengah}

Kriteria Usaha Menengah adalah usaha ekonomi produktif yang berdiri sendiri, yang dilakukan oleh orang perseorangan atau badan usaha yang bukan merupakan anak perusahaan atau cabang perusahaan yang dimiliki, dikuasai, atau menjadi bagian baik langsung maupun tidak langsung dengan Usaha Kecil atau usaha besar dengan jumlah kekayaan bersih atau hasil penjualan tahunan sebagaimana diatur dalam Undang-Undang ini.

\section{Definisi Industri Olahan}

Menurut Kementerian Koperasi dan UMKM (2016) industri pengolahan adalah suatu kegiatan ekonomi yang melakukan kegiatan mengubah suatu barang dasar secara mekanis, kimia atau dengan tangan sehingga menjadi barang jadi, dan atau barang yang kurang nilainya menjadi barang yang lebih tinggi nilainya, dan sifatnya menjadi lebih dekat kepada pemakai akhir, termasuk jasa industri dan pekerjaan perakitan (assembling). Industri olahan diklasifikasikan menjadi sebagai berikut :

1. Industri kimia dasar seperti industri semen, obat-obatan, kertas, dan pupuk.

2. Industri mesin dan logam dasar seperti industri pesawat terbang, kendaraan bermotor dan tekstil. 
3. Industri kecil seperti industri roti, makanan ringan, es, dan minyak goreng curah.

4. Aneka industri seperti industri pakaian, makanan dan minuman.

\section{Definisi Makanan Ringan}

Produk yang termasuk dalam kategori makanan ringan menurut Surat Keputusan Kepala Badan Pengawas Obat dan Makanan Republik Indonesia No. HK.00.05.52.4040 Tanggal 9 Oktober 2006 tentang kategori pangan adalah semua makanan ringan yang berbahan dasar kentang, umbi, serealia, tepung atau pati (dari umbi dan kacang) dalam bentuk keripik, kerupuk, jipang. Selain itu pangan olahan yang berbasis ikan (dalam bentuk kerupuk atau keripik) juga masuk kedalam kategori makanan ringan (Putri, 2011).

\section{Pengembangan Hipotesis}

\section{Pengaruh Marketing Mix Terhadap Minat Beli Konsumen}

Didalam sebuah perusahaan atau sebuah usaha yang menjadi penentu keberhasilan tujuan dari perusahaan tersebut salah satunya adalah sistem pemasaran yang baik. Bauran pemasaran (marketing mix) merupakan suatu strategi penting yang harus dilakukan oleh para pelaku usaha dalam kegiatan pemasaran, dengan kata lain bauran pemasaran menjadi konsep bagi aktivitas perusahaan atau sebuah usaha dalam pencapaian tujuan perusahaan dengan mengefektifkan aktivitas pemasaran.Perusahaan dapat mengandalkan bauran pemasaran dalam upaya menciptakan keunggulan dibandingkan perusahaan lainnya. Dengan mengenali empat unsur bauran pemasaran yaitu produk, harga, tempat dan promosi. Jika perusahaan mampu melakukan kombinasi bauran pemasaran yang tepat maka akan dapat menambah minat beli dibenak konsumen. Berdasarkan uraian diatas dapat dirumuskan hipotesis sebagai berikut.
$\mathrm{H}_{1}$ :Terdapat pengaruh positif dan signifikan marketing mix terhadap minat beli

\section{Pengaruh Produk Terhadap Minat Beli Konsumen}

Pada hakitatnya seseorang membeli produk untuk memuaskan kebutuhan atau keinginan. Seseorang membeli produk bukan hanya fisik semata, melainkan manfaat yang ditimbulkan oleh produk yang dibeli. Bernand (2009) mengatakan bahwa produk merupakan sesuatu yang dapat memberi manfaat, memenuhi kebutuhan konsumen dan dapat memuaskan konsumen. Maka dari itu, seorang pengusaha dituntut untuk selalu kreatif, dinamis, dan berpikiran luas dalam menciptakan serta mengembangkan suatu produk. Menurut Tjiptono (2007) produk yang berkualitas mempunyai hubungan sangat erat dengan sikap konsumen, dimana produk yang memiliki kualitas memberikan suatu dorongan minat kepada konsumen untuk membeli produk tersebut. Karena produk yang ditawarkan akan menggambarkan kondisi perusahaan, jika perusahaan melakukan kesalahan dalam hal pemasaran kepada konsumen dapat menurunkan tingkat minat beli konsumen, bahkan dapat berdampak pada image yang kurang baik. Berdasarkan uraian diatas dapat dirumuskan hipotesis sebagai berikut. $\mathrm{H}_{2}$ : Terdapat pengaruh positif dan signifikan produk terhadap minat beli

\section{Pengaruh Harga Terhadap Minat Beli Konsumen}

Harga adalah sejumlah nilai yang harus dikeluarkan konsumen untuk memperoleh produk (Sutojo, 2009). Penetapan harga merupakan salah satu keputusan terpenting dalam pemasaran. Harga memainkan peran strategik dalam pemasaran. Bila harga terlalu mahal, maka produk yang bersangkutan tidak akan terjangkau oleh pasar sasaran dan minat beli konsumen cenderung menurun terhadap produk tersebut karena dalam membeli suatu produk konsumen tidak hanya 
mempertimbangkan kualitasnya saja, tetapi juga memikirkan kelayakan harga. Harga merupakan salah satu penentu pemilihan produk yang nantinya akan berpengaruh terhadap minat pembelian. Berdasarkan uraian diatas dapat dirumuskan hipotesis sebagai berikut.

$\mathrm{H}_{3}$ : Terdapat pengaruh positif dan signifikan harga terhadap minat beli

\section{Pengaruh Tempat Terhadap Minat Beli Konsumen}

Tempat merupakan faktor yang penting dalam bauran pemasaran (marketing mix), karena pada tempat yang tepat sebuah usaha dapat lebih sukses dari tempat yang memiliki tempat yang kurang strategis, meskipun menjual produk yang sama. Tempat mempunyai hubungan yang positif terhadap minat beli dan faktor merupakan salah satu faktor penting dalam pencapaian tujuan usaha. Didalam bauran pemasaran (marketing mix) place dianggap sebagai suatu keputusan yang harus diterapkan oleh seorang pemilik usaha karena dapat mempengaruhi minat beli yang berujung pada keputusan pembelian produk. Berdasarkan uraian diatas dapat dirumuskan hipotesis sebagai berikut.

H4: Terdapat pengaruh positif dan signifikan tempat terhadap minat beli

\section{Pengaruh Promosi Terhadap Minat Beli Konsumen}

Strategi pemasaran banyak berkaitan dengan komunikasi. Promosi merupakan salah satu bentuk khusus komunikasi untuk memenuhi fungsi pemasaran. Untuk menjalankan fungsi pemasaran, maka hal yang harus dilakukan dalam kegiatan promosi harus lebih dari sekedar memberikan informasi kepada khalayak. Promosi harus mampu membujuk khalayak ramai agar mampu tertarik terhadap suatu produk yang dipromosikan dan berperilaku sesuai dengan strategi pemasaran untuk meningkatkan penjualan dan keuntungan. Promosi akan membawa dan mengarahkan konsumen membeli produk-produk yang telah dirancang oleh produsen guna memenuhi kebutuhan konsumen dan memberikan tingkat kepuasan kepada konsumen. Melalui kegiatan promosi mampu menarik perhatian konsumen untuk membeli produk, serta mampu memberikan respon pembeli yang kuat dan mendongkrak penjualan dalam jangka pendek (Tjiptono, 2007). Berdasarkan uraian diatas dapat dirumuskan hipotesis sebagai berikut :

H5 : Terdapat pengaruh positif dan signifikan promosi terhadap minat beli

Sedangkan paradigma pemikirannya dapat dilihat pada Gambar 1.



Gambar 1 Paradigma penelitian 


\section{Metode Penelitian}

Jenis penelitian yang dipergunakan pada penelitian ialah deskripif yaitu penelitian yang dilakukan untuk menentukan nilai variabel mandiri, baik satu variabel bebas ataupun lebih tanpa membandingkan dengan variabel lain. Dan bentuk penelitian verifikatif diperoleh dengan penyatuan data saat dilapangan yang dipergunakan menguji hipotesis melalui perhitungan statistik (M. Natsir, 1998). Objek pada penelitian kali ini yaitu konsumen UMKM produk olahan makanan ringan di Kota Bogor. Jenis data pada penelitian ini yaitu data primer berupa informasi melalui metode interview serta menggunakan angket kepada konsumen. Data sekunder didapat melalui analisis data yang didapat dari bagian administrasi dan publikasi yang telah diterbitkan. Jumlah sampel yang diambil berjumlah 100 orang, Frankel dan Wallen (1993) berpendapat bahwa besarnya sampel minimun untuk penelitian deskriptif adalah sebanyak 100 sampel.

\section{Metode Analisis}

Variabel yang akan dianalisis dalam penelitian ini adalah Marketing Mix yang memiliki sub variabel terdiri dari variable bebas yaitu Produk $\left(\mathrm{X}_{1}\right)$, Harga $\left(\mathrm{X}_{2}\right)$, Tempat $\left(\mathrm{X}_{3}\right)$ dan Promosi $\left(\mathrm{X}_{4}\right)$. Variabel terikat minat beli konsumen (Y).Oleh karena skala pengukuran dalam data yang dikumpulkan masih skala ordinal. Menurut Umar (2005) maka sebelum dilakukan pengujian dengan regresi berganda, perlu terlebih dahulu menggunakan skala pengukuran yaitu skala likert (1-5).

Untuk mengevaluasi kuesioner apakah pernyataan-pernyataan dalam kuesioner valid dan reliable maka dilakukan uji validitas dan reliabilitas. Uji validitas berfungsi mengetahui sampai mana instrumen dapat mempertimbangkan sesuatu yang diukur (Sugiyono, 2013). Instrumen untuk dinyatakan valid apabila $r_{\text {hitung }} \geq 0,3$. Setelah dikatakan valid maka instrumen akan di uji reliabilitasnya.
Menurut Sugiyono (2013) alat ukur bisa dinyatakan reliabel apabila instrumen yang dipergunakan berkali-kali dalam menakar objek yang sama akan menghasilkan data sama atau apabila jawaban responden pada pertanyaan ialah konsisten dari waktu ke waktu. Adapun kriteria instrumen untuk dikatakan reliabel adalah jika $r_{\text {hitung }} \geq 0,6$. Berdasar perhitungan uji validitas dan reliabilitas terhadap 30 responden untuk variabel marketing mix dan minat beli dari 23 pernyataan, diperoleh hasil bahwa semua item tersebut sudah valid dan reliabel sehingga dapat digunakan dalam instrument penelitian selanjutnya.

Untuk menguji hipotesis, hasil estimasi akan ditaksir dengan metode Ordinary Least Square (OLS). Menurut Agung Abdul Rasul dan Nurlaelah (2010), Ordinary Least Square (OLS) adalah sejumlah asumsi yang menjadi dasar validitas regresi linear berganda. Uji asumsi klasik terdiri dari beberapa hal meliputi uji normalitas, uji multikoloniearitas dan uji heterokedastisitas. Jika regresi linear memenuhi uji asumsi tersebut maka merupakan regresi yang baik. Maka hasil dari pengujian asumsi klasik didapat hasil bahwa seluruh alat ukur pada penelitian ini memenuhi kriteria uji asumsi klasik yaitu seluruh instrumen berdistribusi normal, seluruh instrumen bebas multikoloniearitas dan seluruh instrumen bebas heterokedastisitas. Maka seluruh alat ukur pada penelitian ini bisa dipakai untuk menguji hipotesis.

Tehnik analisis data yang digunakan untuk mengetahui pengaruh antar-variabel marketing mix terhadap minat beli konsumen dalam penelitian ini adalah analisis regresi berganda, besarnya pengaruh antar variabel dinyatakan pada struktur pengaruh variabel tersebut dinyatakan ke dalam persamaan regresi $\mathrm{Y}$ atas $X_{1}, X_{2}, X_{3}, X_{4}$ (Danang,2003) sebagai berikut: $Y=a+b_{1} X_{1}+b_{2} X_{2}+b_{3} X_{3}+b_{4} X_{4}+\varepsilon$, sedangkan pengujian hipotesis dilakukan dengan menggunakan uji t, uji F dan uji $\mathrm{R}^{2}$. 


\section{HASIL DAN PEMBAHASAN}

\section{Karakteristik Responden}

Karakteristik konsumen terbanyak adalah perempuan sebesar $62 \%$ karena merupakan orang yang sering melakukan pembelian, sebagai penentu pengambilan keputusan terhadap apa yang mau dibeli dan dikonsumsi. Sebanyak 37\% mayoritas responden berusia 26 - 35 tahun, ini digambarkan diamana pada usia tersebut merupakan usia produktif. Mayoritas responden yaitu sebesar 54\% berpendidikan SMA, karena dalam melakukan pembelian produk makanan ringan di Kota Bogor tidak berdasar pada batasan pendidikan, pada umumnya produk tersebut dapat dikonsumsi disegala tingkat pendidikan. Dan sebanyak 33\% rata-rata mayoritas responden berpendapatan $\mathrm{Rp}$. 3.000 .000 - Rp. 4.000.000/bulan, ini menggambarkan produk UMKM olahan makanan ringan dapat dijangkau oleh konsumen yaitu kisaran Rp. 2.000 - Rp. 35.000 .

\section{Tanggapan Konsumen Terhadap Marketing Mix dan Minat Beli Konsumen}

\section{Tanggapan Konsumen Terhadap Variabel Produk}

Produk adalah segala sesuatu yang ditawarkan untuk memuaskan suatu kebutuhan dan keinginan (Kotler, 2005). Indikator produk terdiri dari variasi produk, kualitas produk, citra merek serta packaging produk. Hasil tanggapan konsumen pada atribut dimensi produk adalah sebesar 82,8 persen dalam kategori Baik. Artinya pada umumnya produk olahan makanan ringan UMKM dikota Bogor sangat bervariasi, berkualitas, memiliki citra yang baik serta memiliki packaging yang menarik. Tanggapan sangat bervariasi menunjukkan bahwa konsumen berpendapat bahwa produk olahan makanan ringan UMKM di Kota Bogor memiliki banyak pilihan variasi produk, sehingga konsumen memiliki banyak alternatif pilihan dalam memilih produk yang akan dibeli.Tanggapan berkualitas hal tersebut menunjukkan bahwa menurut konsumen produk olahan makanan ringan UMKM di Kota Bogor memiliki kualitas yang baik, kualitas produk dapat dilihat dari ratarata produk olahan makanan ringan UMKM di Kota Bogor telah mencantumkan izin dari departemen kesehatan dan telah mencantumkan tangggal kedaluwarsa hal tersebut dapat medorong minat beli konsumen terhadap produk olahan makanan ringan di Kota Bogor. Seperti yang dikemukakan oleh Mayasari dan Suwarni (2009) dalam bahwa kualitas produk berpengaruh positif dan signifikan terhadap kepuasan konsumen dan pada akhirnya berdampak pada loyalitas konsumen. Kualitas produk yang baik dapat memberikan pengalaman positif berupa kepuasan konsumen dan minat beli sehingga hal tersebut membuat konsumen cenderung memilih produk tersebut kembali dikesempatan berikutnya. Sedangkan, menurut Tjiptono (2007) semakin baik kualitas produk yang diberikan maka konsumen akan semakin berminat untuk melakukan pembelian. Tanggapan citra merek baik menunjukkan bahwa konsumen berpendapat produk olahan makanan ringan UMKM di Kota Bogor memiliki citra merek yang sudah baik dan sudah dikenali. Pada persaingan yag rendah merek hanya sekedar nama (just a name). Namun pada persaingan yang tinggi, merek memberikan kontribusi dalam menciptakan dan menjaga daya saing sebuah produk. Merek akan dihubungkan dengan citra khusus yang mampu memberikan nilai tertentu dalam benak konsumen (Aaker, 2001).UMKM juga diharapkan meningkatkan integritas citra mereknya dengan menjaga reputasi, mutu dan kualitas produk yang ditawarkan, serta keunggulan-keunggulan lainnya seperti pelayanan yang baik, untuk meningkatkan kepercayaan pelanggan terhadap produk. Indentitas produk yang diperkuat oleh integritas merek dapat membentuk citra 
merek yang kuat untuk mempersiapkan diri bersaing dipasar MEA. Citra merek dan keputusan pembelian sangat erat kaitannya, karena konsumen sebelum melakukan pembelian menempatkan citra merek sebagai salah satu pertimbangan dalam pengambilan keputusan pembelian. Suatu produk dengan citra yang baik diyakini konsumen dapat memenuhi kebutuhan dan keinginannya, maka dengan sendirinya akan menumbuhkan keputusan pembelian konsumen akan suatu produk yang ditawarkan. Hal tersebut sebaliknya apabila produk dengan citra merek yang kurang baik dalam pandangan konsumen, maka keputusan pembelian konsumen terhadap produk juga akan lebih rendah. Meskipun citra merek bukan satu-satunya variabel yang menentukan untuk memilih produk akan tetapi variabel citra merek cukup memberi andil yang membuat konsumen memilih dan membeli produk yang ditawarkan.Tanggapan konsumen terhadap packaging produk yang menarik menunjukkan bahwa konsumen berpendapat rata-rata produk olahan makanan ringan UMKM di Kota Bogor telah memiliki packaging yang menarik. Seperti yang dikemukakan Rundh (2005) dengan kemasan dapat menarik perhatian konsumen terhadap merek tertentu, meningkatkan citra dan merangsang persepsi konsumen tentang produk. Kemudian kemasan juga menyampaikan nilai khas suatu produk. Dan Wells Farley (2007) mengatakan biasanya konsumen akan cenderung memilih produk makanan dengan kemasan menarik dibandingkan dengan produk kemasan yang polos atau sederhana dan tidak menarik. Bahkan dengan produk yang sama, namun menggunakan kemasan yang berbeda dapat mempengaruhi minat pembelian pada konsumen.

\section{Tanggapan Konsumen Terhadap Variabel Harga}

Harga adalah sejumlah nilai yang harus dikeluarkan konsumen untuk memperoleh produk (Sutujo, 2009). Indikator harga terdiri dari keterjangkauan harga, kesesuaian harga dengan kualitas produk, perbandingan harga produk dengan pesaing. Hasil tanggapan konsumen pada atribut dimensi harga adalah sebesar 80,2 persen termasuk pada kategori baik. Artinya pada umumnya harga produk olahan makanan ringan UMKM dikota Bogor masih terjangkau, harga sesuai dengan kualitas yang ditawarkan, harga bersaing dengan produk lain. Tanggapan konsumen harganya terjangkau menunjukkan bahwa konsumen berpendapat produk olahan makanan ringan UMKM di Kota Bogor memiliki harga yang terjangkau. Jika produk-produk olahan makanan ringan UMKM di Kota Bogor terjangkau maka dapat meningkatkan daya beli konsumen dari berbagai kalangan. Tanggapan konsumen terhadap harga produk olahan makanan ringan sesuai atau sebanding dengan kualitas produk menunjukkan bahwa konsumen berpendapat produk olahan makanan ringan UMKM di Kota Bogor memiliki harga yang sebanding dengan kualitas produk. Ini akan membuktikan bahwa jumlah nilai yang dikeluarkan konsumen untuk memperoleh sebuah produk makanan ringan di Kota Bogor sebanding dengan kualitas yang didapatkan terbukti dengan tanggapan konsumen terhadap variabel produk adalah Tinggi. Keseuaian harga dengan produk yang didapat mempengaruhi minat beli konsumen, apabila harga yang dibayar sebanding dengan kualitas produk yang didapat maka minat beli konsumen akan meningkat dan begitu pun sebaliknya.Tanggapan konsumen terhadap harga produk olahan makanan ringan UMKM di Kota Bogor bersaing atau sebanding dengan tempat lain menunjukkan bahwa konsumen berpendapat produk UMKM olahan makanan ringan di Kota Bogor memiliki harga yang bersaing dengan tempat lain. Menurut Cahya dan Simanjuntak (2012) dalam penelitiannya menyatakan bahwa harga yang kompetitif selalu diingat oleh konsumen, dan akan membuat konsumen datang kembali untuk membeli produk tersebut. 


\section{Tanggapan Konsumen Terhadap Variabel Tempat}

Tempat adalah seperangkat organisasi yang saling bergantung satu sama lain, yang dilibatkan dalam proses penyediaan suatu produk atau jasa untuk digunakan atau dikonsumsi (Kotler dan Amstrong, 2010). Indikator tempat terdiri dari tempat dan lokasi yang strategis, keamanan tempat menjual terjaga, tampilan fasilitas-fasilitas fisik menarik, ketersediaan produk. Hasil tanggapan konsumen pada atribut dimensi trmpat adalah sebesar 67,4 persen termasuk pada kategori baik. Artinya pada umumnya lokasi atau saluran distribusi produk makanan ringan UMKM dikota Bogor memiliki lokasi strategis, keamanan tempat menjual cukup terjaga, display penjualan cukup menarik dan ketersediaan produk cukup baik. Tanggapan konsumen terhadap lokasi penjualan strategis menunjukkan bahwa rata-rata produk UMKM olahan makanan ringan di Kota Bogor dijual di tempat yang strategis hal tersebut memudahkan akses para konsumen untuk mendapatkan produk yang diinginkan.Tanggapan konsumen terhadap indikator keamanan tempat menjual cukp terjaga menunjukkan bahwa konsumen berpendapat keamanan tempat menjual produk UMKM olahan makanan ringan di Kota Bogor terjaga sehingga memberikan rasa aman kepada konsumen ketika sedang melakukan pembelian pada tempat menjual produk UMKM olahan makanan ringan di Kota Bogor.Tanggapan konsumen terhadap indikator display tempat menjual cukup menarik menunjukkan bahwa konsumen berpendapat bahwa rata-rata tempat menjual produk olahan makanan ringan di Kota Bogor memiliki display yang menarik.Menurut Tjiptono (2002) pemilihan tempat/lokasi yang tepat harus memperhatikan serta mempertimbangkan beberapa aspek yaitu akses, visibilitas, lalu lintas, tempat parkir luas dan terjaga, ekspansi, lingkungan persaingan dan peraturan pemerintah. Sedangkan menurut Kotler,Keller (2009), lokasi atau tempat juga harus bisa memasarkan atau mempromosikan dirinya sendiri. Lokasi atau tempat pada dasarnya melakukan empat aktivitas yaitu 1) menghadirkan lokasi yang strategs sehingga memudahkan konsumen, 2) lokasi atau tempat akan mempromosikan nilai dan citra dari tempat itu sendiri sehingga konsumen bisa membedakannya dengan toko lain, 3) produk yang ditawarkan harus sesuai dengan keinginan konsumen, 4) harga yang ditawarkan harus bisa menarik konsumen dan memperkuat citra yang ingin dibentuk.

\section{Tanggapan Konsumen Terhadap Variabel Promosi}

Promosi adalah kegiatan mengkomunikasikan manfaat sebuah produk dan membujuk target konsumen untuk membeli produk tersebut (Kotler dan Amstrong, 2012). Indikator promosi terdiri dari informasi tentang produk informatif, sumber informasi tersedia banyak, informasi produk mendorong melakukan pembelian, pesan promosi yang disampaikan mudah diingat. Hasil tanggapan konsumen pada atribut variabel promosi adalah sebesar 66,2 persen termasuk pada kategori cukup baik. Artinya pada umumnya promosi yang telah dilakukan oleh UMKM memiliki informasi mengenai produk cukup informatif, sumber informasi cukup tersedia, informasi produk mendorong konsumen dalam melaksanakan pembelian, serta pesan promosi cukup mudah diingat. Tanggapan konsumen terhadap informasi tentang cukup informatif menunjukkan bahwa konsumen berpendapat informasi tentang produk mampu memberikan informasi yang jelas kepada para konsumen. Informasi yang informatif dapat meningkatkan daya beli konsumen karena dengan mengetahui lebih banyak informasi tentang produk UMKM makanan ringan di Kota Bogor akan semakin menambah pengetahuan konsumen tentang produk sebelum membeli. Tanggapan konsumen mengenai sumber informasi cukup tersedia menunjukkan bahwa konsumen berpendapat informasi tentang produk 
UMKM olahan makanan ringan tersedia banyak hal ini memudahkan konsumen dalam memperoleh informasi tentang produk tersebut.Tanggapan konsumen mengenai informasi produk mendorong untuk melakukan pembelian menunjukkan konsumen berpendapat bahwa informasi dalam promosi yang dilakukan oleh para pelaku usaha produk UMKM olahan makanan ringan di Kota Bogor mendorong konsumen dalam melakukan pembelian. Tanggapan konsumen mengenai pesan promosi yang disampaikan cukup mudah diingat menunjukkan bahwa konsumen berpendapat pesan promosi yang disampaikan mudah diingat sehingga konsumen akan terus ingat pada produkproduk tersebut. Promosi berperan dalam menghasilkan penyampaian informasi yang baik pada konsumen akan manfaat atau kelebihan suatu produk, sehingga dapat mempengaruhi benak konsumen dan akan menimbulkan minat untuk membeli produk tersebut (Tjiptono, 2007).

\section{Tanggapan Konsumen Terhadap Variabel Minat Beli Konsumen}

Minat beli adalah minat beli merupakan sesuatu yang berhubungan dengan rencana konsumen untuk membeli produk tertentu serta berapa banyak unit produk yang dibutuhkan pada periode tertentu (Ferdinand, 2002). Indikator minat beli terdiri dari minat transaksional, minat referensial, minat preferensial dan minat eksploratif. Hasil tanggapan konsumen pada atribut variabel minat beli konsumen adalah sebesar 71,4 persen termasuk pada kategori tinggi. Artinya pada umumnya minat beli konsumen terhadap produk olahan makanan ringan memiliki penilaian mina untuk bertransaksi yang tinggi, minat untuk mereferensikan produk yang cukup tinggi, minat pada produk yang disukainya tinggi serta minat untuk mengeksplorasi produk juga tinggi. Tanggapan konsumen mengenai atribut melakukan pembelian hanya untuk kegiatan transaksi tinggi menunjukkan bahwa konsumen melakukan pembelian hanya sebagai kegiatan transaksi pemenuh keinginan akan produk tersebut. Tanggapan konsumen atribut melakukan pembelian untuk merekomendasikan kepada keluarga/kerabat cukup tinggi menunjukkan bahwa tidak semua konsumen yang melakukan pembelian bersedia untuk merekomendasikan kepada keluarga/kerabat karena mayoritas konsumen membeli karena telah memiliki produk yang disukai dan hanya sekedar menjadikannya kegiatan transaksi. Tanggapan konsumen melakukan pembelian karena suka dengan produknya tinggi menunjukkan bahwa mayoritas konsumen melakukan pembelian karena telah memiliki produk yang disukainya.Tanggapan konsumen melakukan pembelian hanya untuk mencoba-coba (mencari pengalaman) tinggi menunjukkan bahwa konsumen melakukan pembelian hanya untuk mengeksplor tentang makanan-makanan ringan di Kota Bogor agar mendapat pengalaman dalam berkuliner.

\section{Pengaruh Marketing Mix Terhadap Minat Beli Konsumen}

Bentuk persamaan dihitung dengan menggunakan analisis regresi linear berganda. Adapun persamaan tersebut adalah untuk menunjukkan pengaruh marketing mix terhadap minat beli konsumen. Hasil regresi secara ringkas dapat dilihat pada Tabel 1. Berdasar tabel 1 menunjukkan bahwa bentuk persamaan dengan menggunakan analisis regresi linear berganda $Y=4,016+0,413 X_{1}+0,315 X_{2}+$ $\mathbf{0 , 1 0 9} X_{3}+0,177 X_{4}+\varepsilon$. Persamaan tersebut menunjukkan pengaruh marketing mix terhadap minat beli konsumen, dari hasil penelitian, maka diperoleh suatu persamaan regresi dengan model taksiran seperti berikut ini..

Berdasarkan persamaan tersebut menunjukkan nilai $\beta_{1}=0,413$ berarti setiap terjadi kenaikan pada nilai produk maka diduga akan diikuti dengan kenaikan minat beli konsumen (Y) sebesar $41,3 \%$ dan $\mathrm{X}_{2}, \mathrm{X}_{3}$, dan $X_{4}$ tetap. Nilai $\beta_{2}=0,315$ berarti setiap 
terjadi kenaikan pada nilai harga maka diduga akan diikuti dengan kenaikan minat beli konsumen (Y) sebesar 31,5\% dan $\mathrm{X}_{1}, \mathrm{X}_{3}$, $\mathrm{X}_{4}$ tetap. Nilai $\beta_{3}=0,109$ berarti setiap terjadi kenaikan nilai tempat maka diduga akan diikuti dengan kenaikan minat beli konsumen (Y) sebesar 10,9\% dan $\mathrm{X}_{1}, \mathrm{X}_{2}$, dan $\mathrm{X}_{4}$ tetap. Nilai $\beta_{4}=0,177$ berarti setiap terjadi kenaikan pada nilai promosi maka diduga akan diikuti dengan kenaikan minat beli konsumen (Y) sebesar $17,7 \%$ dan $\mathrm{X}_{1}, \mathrm{X}_{2}$, dan $\mathrm{X}_{3}$ tetap.

Tabel 1 Rangkuman hasil perhitungan persamaan regresi

\begin{tabular}{|c|c|c|c|c|}
\hline Variabel & B & $\begin{array}{c}\mathrm{t} \\
\text { hitung }\end{array}$ & Sig $t$ & Beta \\
\hline Constant & 4,016 & 2,060 & 0,042 & \\
\hline $\begin{array}{l}\text { Produk } \\
\left(\mathrm{X}_{1}\right)\end{array}$ & 0,413 & 4,646 & 0,000 & 0,453 \\
\hline $\begin{array}{l}\text { Haega } \\
\left(X_{2}\right)\end{array}$ & 0,315 & 4,661 & 0,000 & 0,398 \\
\hline Tempat & 0,109 & 1,548 & 0,125 & 0,100 \\
\hline $\begin{array}{l}\left(\mathrm{X}_{3}\right) \\
\text { Promosi } \\
\left(\mathrm{X}_{4}\right)\end{array}$ & 0,177 & 0,778 & 0,439 & 0,092 \\
\hline $\mathrm{t}$ table & $=1,660$ & & & \\
\hline $\mathrm{R}$ & $=0.796$ & & & \\
\hline R Square & $=0,634$ & & & \\
\hline $\begin{array}{l}\text { Adjusted } \\
\text { R Square }\end{array}$ & $=0,618$ & & & \\
\hline F hitung & $\begin{array}{l}= \\
41,090\end{array}$ & & & \\
\hline F tabel & $=2,46$ & & & \\
\hline Sig F & $=0,000$ & & & \\
\hline SEE & $\begin{array}{l}= \\
2,05578\end{array}$ & & & \\
\hline
\end{tabular}

\section{Hasil Analisis Korelasi Berganda}

Analisis korelasi berganda dilakukan untuk menganalisis atau melihat keeratan hubungan antara variabel independen marketing mix (produk, harga, tempat dan promosi) terhadap variabel dependen minat beli konsumen, dengan melihat nilai $R$.Berdasarkan hasil yang diperoleh dari nilai $R$, hubungan antara marketing mix terhadap minat beli konsumen pada produk olahan makanan ringan di Kota Bogor menunjukkan angka korelasi 0,796 berada pada kategori Kuat. Artinya bahwa semakin baik dan semakin tepat pelaksanaan bauran pemasaran maka minat beli konsumen pada UMKM produk olahan makanan ringan di Kota Bogor semakin meningkat.

\section{Pengujian Koefisien Determinasi}

Analisis koefisien determinasi memperlihatkan seberapa besar sumbangan persentase pengaruh marketing mix (produk, harga, tempat, promosi) pada minat beli konsumen. Diperloleh nilai koefisien determinasi $R$ Square sebesar 0,634 atau 63,4\%. Hal tersebut memperlihatkan persentase sumbangan pengaruh variabel faktor marketing mix (produk, promosi, harga dan tempat) terhadap minat beli konsumen UMKM produk olahan makanan ringan di Kota Bogor sebesar 63,4\%. Sedangkan, sisanya $36,6 \%$ dipengaruhi variabel diluar penelitian yang tidak dimasukan dalam model penelitian ini seperti potongan harga, persepsi konsumen, kualitas layanan dan lainnya.

\section{Pengujian Model Regresi Secara Simultan (Uji F)}

Membuktikan bersama-sama / simultan variabel marketing mix (produk, harga, tempat, promosi) terhadap minat beli konsumen mempergunakan statistik uji-F. Dan darihasil perhitungan diperoleh abhwa nilai $\mathrm{F}_{\text {hitung }}$ sebesar 41,090 dan $\mathrm{F}_{\text {tabel }}$ untuk $\alpha$ $=0,05$ dengan derajat kebebasan $\mathrm{V} 1=3$ dan $\mathrm{V} 2=95$ sebesar 2,46 yang dimana bisa dilihat bahwa $F_{\text {hitung }}$ lebih besar dari $F_{\text {tabel }}$ $(41,090>2,46)$ bisa disimpulkan $\mathrm{H}_{0}$ ditolak dan $\mathrm{H}_{\mathrm{a}}$ diterima artinya dengan ringkat kepercayaan 95\% variabel independen produk $\left(\mathrm{X}_{1}\right)$, harga $\left(\mathrm{X}_{2}\right)$, tempat $\left(\mathrm{X}_{3}\right)$ dan promosi $\left(\mathrm{X}_{4}\right)$ berpengaruh positif dan signifikan secara simultan terhadap minat beli konsumen pada UMKM produk olahan makanan ringan di Kota Bogor (Y). Hal ini seperti yang dikemukakan Alma (2005) berpendapat bahwa analisis kemampuan 
strategi pemasaran suatu produk terletak pada penguasaan, impilkasi serta pemahaman mengenai cara-cara strategi pemasaran berpusat pada marketing mix/bauran pemasaran. Dimana bauran pemasaran yang terkait seperti produk, harga, tempat dan promosi. Sehingga disarankan bagi pengembang strategi pemasaran untuk terus menerapkan kombinasi bauran pemasaran secara baik, karena akan mengarah pada kepuasan pelanggan sehingga minat beli dapapt meningkat serta meningkatkan persaingan tinggi pada produk.

\section{Pengujian Koefisien Regresi Secara Parsial (Uji-t)}

Berdasarkan perhitungan diperoleh hasil pengujian setiap variabel bebas (produk, harga, tempat, promosi) tehadap minat beli konsumen yaitu :

1. Pengaruh Produk $\left(\mathrm{X}_{1}\right)$ Terhadap Minat Beli Konsumen (Y)

Hasil perhitungan pada tabel diperoleh $t_{\text {hitung }}$ pada variabel produk $\left(\mathrm{X}_{1}\right)$ sebesar 4,646 dan nilai tabel untuk $\alpha=0,05$ dengan derajat kebebasan 100-4-1 = 95 sebesar 1,660 berarti $t_{\text {hitung }}>t_{\text {tabel }}(4,646$ $>$ 1,660). Maka $\mathrm{H}_{\mathrm{a}}$ diterima dan $\mathrm{H}_{0}$ ditolak, artinya faktor produk $\left(\mathrm{X}_{1}\right)$ berpengaruh positif dan signifikan terhadap minat beli konsumen pada UMKM produk olahan makanan ringan di Kota Bogor (Y). Didukung dengan pendapat dari Tjiptono (2007), mengatakan jika semakin baik kualitas produk yang diberikan maka semakin berkeinginan untuk membeli produk.

2. Pengaruh Harga $\left(X_{2}\right)$ Terhadap Minat Beli Konsumen ( $\mathrm{Y}$ )

Hasil perhitungan pada tabel diperoleh $t_{\text {hitung }}$ pada variabel harga $\left(\mathrm{X}_{2}\right)$ sebesar 4,661 dan nilai tabel untuk $\alpha=0,05$ dengan derajat kebebasan 100-4-1 = 95 sebesar 1,660. Maka $\mathrm{H}_{\mathrm{a}}$ diterima dan $\mathrm{H}_{0}$ ditolak, artinya faktor harga $\left(\mathrm{X}_{2}\right)$ berpengaruh positif dan signifikan terhadap minat beli konsumen pada UMKM produk olahan makanan ringan di Kota Bogor (Y). Kotler dan Keller (2007) mengatakan bahwa harga ialah bagian dari atribut dari marketing mix yang menjadi pertimbangan seseorang melakukan pembelian produk dengan keterlibatan tinggi.

3. Pengaruh Tempat $\left(\mathrm{X}_{3}\right)$ Terhadap Minat Beli Konsumen (Y)

Hasil perhitungan pada tabel diperoleh thitung pada variabel tempat $\left(\mathrm{X}_{3}\right)$ sebesar 1,548 dan nilai $t_{\text {tabel }}$ untuk $\mathrm{a}=0,05$ dengan derajat kebebasan 100-4-1 = 95 sebesar 1,660 berarti $t_{\text {hitung }}<t_{\text {tabe }} l(1,548$ $<$ 1,660). Maka $\mathrm{H}_{0}$ diterima dan $\mathrm{H}_{\mathrm{a}}$ ditolak, artinya faktor tempat tidak berpengaruh positif dan signifikan terhadap minat beli konsumen pada UMKM produk olahan makanan ringan di Kota Bogor (Y).Hasil penelitian tersebut didukung dengan penelitian Lin (2011) yang berjudul Marketing Mix (7P) and Performance Assesment of Wastern Food Industry in Taiwan mengatakan bahwa faktor tempat tidak berpengatuh pada keputusan. Kepuasan pelanggan akan produk membuat pelanggan tersebut menjadi loyal pada produk ataupun unit usahanya.

4. Pengaruh Promosi (X4) Terhadap Minat Beli Konsumen (Y)

Hasil perhitungan pada tabel diperoleh $t_{\text {hitung }}$ pada variabel promosi $\left(\mathrm{X}_{4}\right)$ sebesar 0,778 dan nilai tabel untuk $\alpha=0,05$ dengan derajat kebebasan 100-4-1 = 95 sebesar 1,660 berarti $t_{\text {hitung }}<t_{\text {tabel }}(0,778$ $<$ 1,660). Maka $\mathrm{H}_{0}$ diterima dan $\mathrm{H}_{\mathrm{a}}$ ditolak, berarti faktor promosi $\left(\mathrm{X}_{4}\right)$ tidak berpengaruh positif dan signifikan terhadap minat beli konsumen pada UMKM produk olahan makanan ringan di Kota Bogor (Y). Hal ini sejalan dengan pendapat konsumen yang diperolah pada saat wawancara yang mengatakan bahwa produsen setingkat UMKM masih belum mampu mengeluarkan biaya untuk kegiatan promosi. 


\section{Faktor Dominan yang Mempengaruhi Minat Beli Konsumen}

Adapun faktor dominan yang mempengaruhi minat beli konsumen terdapat pada nilai koefisien pada persamaan regresi yaitu pada variabel produk Hal tersebut diartikan bahwa produk adalah variabel yang kuat berpengaruh pada minat beli konsumen.

\section{KESIMPULAN DAN IMPLIKASI}

Dari hasil penelitian dan pembahasan disimpulkan bahwa :

1. Rata-rata jawaban konsumen terhadap marketing mix, untuk produk diperoleh rata-rata sebesar 4,14 dengan interpretasi Baik. Kemudian untuk harga diperoleh nilai rata-rata sebesar 4,01 dengan interpretasi Baik. Lalu untuk tempat diperoleh nilai rata-rata 3,57 dengan interpretaasi Cukup Baik. Untuk promosi diperoleh nilai rata-rata 3,31 dengan interpretasi Cukup Baik. Terakhir untuk minat beli diperoleh nilai rata-rata 3,57 dengan interpretasi Tinggi.

2. Dari hasil Uji F bahwa produk, harga, tempat dan promosi secara simultan berpengaruh secara positif dan signifikan pada minat beli konsumen pada UMKM produk olahan makanan ringan di Kota Bogor.

3. Berdasarkan hasil Uji $t$ bahwa produk dan harga berpengaruh positif dan signifikan pada minat beli konsumen, sedangkan tempat dan promosi tidak berpengaruh positif dan signifikan terhadap minat beli konsumen.

4. Berdasarkan hasil pengujian koefisien regresi dapat diketahui bahwa faktor yang paling dominan pada dimensi marketing mix pada minat beli konsumen UMKM produk olahan makanan ringan di Kota Bogor adalah variabel produk.
Berdasarkan hasil penelitian, ada beberapa masukan mengenai marketing mix terhadap minat beli konsumen, antara lain :

1. Berdasarkan pada hasil rekapitulasi tanggapan responden penilaian terendah terdapat pada variabel promosi yaitu ketersediaan sumper tentang produk. Pihak UMKM disarankan untuk tetap membuat produk yang unik, memiliki kelebihan serta memperoleh produk berkualitas, sehingga konsumen dapat merasa puas dan bersedia mempromosikan produk dengan mouth to mouth. Lalu pihak UMKM dapat memanfaatkan internet marketing melalui media seperti (facebook, instagram, twitter dan lain sebagainya). Karena kemajuan globalisasi membuat konsumen lebih sering mengakses media sosial untuk mendapatkan informasi tentang berbagai hal. Dengan memanfaatkan internet, bisnis akan mempunyai peluang dalam mencapai pasar yang luas.

2. Bagi yang akan melaksanakan penelitian lanjutan tentang manajemen pemasaran di UMKM produk olahan makanan ringan di Kota Bogor hendaknya memperdalam kajian mengenai faktorfaktor yang mempengaruhi minat beli selain marketing mix seperti potongan harga, persepsi konsumen dan lain sebagainya, sehingga penelitian ini dijadikan sebagai tambahan data.

\section{UCAPAN TERIMA KASIH}

Ucapan terima kasih kepada Dinas Koperasi dan UMKM Kota Bogor yang telah memberi ijin melakukan penelitian di UMKM Kota Bogor.

\section{DAFTAR PUSTAKA}

Aaker, A David. 2001. Marketing Research. John Willey \& Sons Ltd. New York.

Agung Abdul Rasul dan Nurlaelah. 2010. Praktikum Statistik Ekonomi Bisnis 
dengan SPSS. Penerbit Mitra Wacana Media. Jakarta

Assauri, Sofjan. 2007. Manajemen Pemasaran. Rajawali Press. Jakarta.

Basu, Swastha. 2000. Manajemen Pemasaran Modern. PT Raja Grafindo Persada. Jakarta.

Basu, Swastha. 2005. Manajemen Pemasaran dan Pemasaran Jasa. Cetakan Kelima. Alfabeta. Bandung.

Cahya, Yohana F dan Simanjuntak, Sahat. 2012. Faktor Yang Mempengaruhi Minat Beli Produk Makanan dan Minuman Usaha Kecil Menengah Kabupaten Tangerang. Jurnal Manajemen dan Kewirausahaan. Vol.14, No.2, hal 8-15

Dinas Koperasi dan UMKM Kota Bogor, 2016. Perkembangan Jumlah UMKM Produk Olahan Makanan Ringan di Kota Bogor Tahun 2012-2015.

Dinas Koperasi dan UMKM Kota Bogor, 2016. Jenis Produk Olahan Makanan Ringan di Kota Bogor Tahun 2015.

Durianto, Darmadi, dkk. 2003. Inovasi Pasar Dengan Iklan Yang Efektif. Gramedia. Jakarta

Faradiba. 2013. Analisis Pengaruh Produk, Harga, Lokasi dan Kualitas Pelayanan Terhadap Minat Beli Ulang Konsumen. Diponegoro Journal of Management. Vol. 2 No.3 Tahun 2013, halaman 1-11 : 23373792.

Ferdinand, Augusty. 2002. Pengembangan Minat Beli Merek Ekstensi. Badan Penerbit Universitas Diponegoro. Semarang.

Frankel, J dan Wallen, N. 1993. How to Design and Evaluate Research in Education (2nd ed). Mc Graw-Hill Inc.Newyork.

Husein, Umar. 2005. Metode Penelitian. Salemba Empat. Jakarta.

Kotler. 2002. Manajemen Pemasaran. Jilid 1. Edisi Milenium. Prehallindo. Jakarta.

Kotler. 2005. Manajemen Pemasaran. Jilid I dan II. PT Indeks. Jakarta.

Kotler, Amstrong. 2010. Principles of Marketing. 13 Edition. New Jersey. Upper Saddle. River. Pearson Prentice Hall.
Kotler, Amstrong. 2012. Prinsip-prinsip Pemasaran. Edisi 13. Jilid 1. Andi. Yogyakarta.

Kotler dan Keller, 2007. Manajemen Pemasaran. Jilid 1. Edisi 12. PT.Indeks. Jakarta.

Kotler. Keller. 2009. Manajemen Pemasaran. Jilid I. Edisi Ketiga Belas. Erlangga. Jakarta.

Lin, S,M. 2011. Marketing Mix (7P) and Performance Assesment of Wastren Food Industry in Taiwan. African Journal of Bussiness Management 5 : 10635-10644.

M. Natsir. 1998. Metode Penelitian. Ghalia Indonesia: Jakarta.

Mayasari S. D dan Suwarni. 2009. Pengaruh Kualitas Produk Terhadap Loyalitas Melalui Kepuasan Konsumen. Jurnal Ekonomi Bisnis. Vol. 16. No.1 halaman 74-86.

Putri, A. 2011. Makanan Ringan Ekstrudat. repository.us.u.ac.id/bitstream/1234567 89/ekstrudat/25614/chapter\%2011.pdf (Didownload : Sabtu, 29-10-16/22.02)

Rundh, B. 2005. The multi-faceted Dimension of Packaging British Food Journal. 107(9), 607-684.

Senjaya, Harry, G. 2014. Pengaruh Bauran Pemasaran Terhadap Keputusan Pembelian Masakan Jepang di Hayashi Teppan. E-journal Graduate Unpar. Vol.1, No.2 (2014) : 2355-4304.

Siswanto, Sutojo. 2009. Manajemen Pemasaran. Edisi Kedua. Damar Mulia Pustaka. Jakarta.

Sugiyono.2013. Metode Penelitian Kuantitatif, Kualitatif, Kombinasi (Mixed Methods). Alfabeta. Bandung.

Sunyoto, Danang. 2009. Analisis Regresi dan Uji Hipotesis. Edisi Pertama. Media Pressindo: Yogyakarta.

Surat Keputusan Kepala Badan Pengawas Obat dan Makanan Republik Indonesia No. HK.00.05.52.4040 Tanggal 9 Oktober 2006 tentang kategori pangan

Tjiptono, Fandy. 2002. Strategi Pemasaran. Andi. Yogyakarta.

Tjiptono, Fandy. 2007. Strategi Pemasaran. Edisi Kedua. Andi. Yogyakarta. 
Wantini, Saiz. 2013. Pengaruh Bauran Pemasaran Terhadap Keputusan Pembelian Emping Mlinjo di Kelurahan Ngadirejo Kecamatan Kartasura. Jurnal Pendidikan Bisnis dan Ekonomi. Vol.1 No.1 Tahun 2013. 72-78.
Wells, L., Farley, H \& Amstrong G.A. 2007. The Importance of Packaging Design For Own -label Foodbrands. International Journal of Retail and Distribution Management, 35(9), 677-690. 